\title{
ANTIENDOMYSIUM ANTIBODIES IN BRAZILIAN PATIENTS WITH CELIAC DISEASE AND THEIR FIRST-DEGREE RELATIVES
}

\author{
Lorete Maria da Silva KOTZE*, Shirley Ramos da Rosa UTIYAMA**, \\ Renato Mitsunori NISIHARA**, Márgara Patrícia Bini ZENI**, \\ Margareth Gomes de SENA*** and Heda Maria Santos AMARANTE***
}

ABSTRACT - Background - Literature data have shown high specificity of antiendomysial antibodies (EmA IgA) in celiac disease. The scarcity of Brazilian reports concerning this subject motivated the present study. Objectives - To determine the sensitivity and specificity of antiendomysial IgA antibodies in Brazilian celiac patients at diagnosis and after treatment, to confirm patient adherence to a gluten-free diet and to screen first-degree relatives. Methods - An extensive clinical and serological study was performed by investigating the presence of these antibodies in 392 individuals from Southern Brazil. Indirect immunofluorescence using human umbilical cord as substrate was employed and the total levels of IgA were determined by turbidimetry in all groups. The study was conducted on 57 celiac patients (18 at diagnosis, 24 who adhered to a gluten-free diet and 15 with marked or slight transgression of the diet), 115 relatives of celiac patients (39 families), 94 patients with other gastrointestinal diseases, and 126 healthy individuals from the general population. Results - The results demonstrated $100 \%$ positivity for the recently diagnosed patients and for those consuming gluten, in contrast to the patients who complied with the diet (0\%). In the control group one individual was positive, but refused to undergo a biopsy. In the group of other gastrointestinal diseases, one positive patient presented ulcerative colitis, Down's syndrome and epilepsy, and the intestinal biopsy was diagnostic for celiac disease. These data showed $99.3 \%$ specificity for the test. Eighteen relatives were positive for antiendomysial antibodies IgA (15.65\%), and comparison with the healthy population revealed a significant difference. An intestinal biopsy was obtained from seven subjects (one with total villous atrophy and six withouth alterations in the mucosal architecture, but all with a high number of intra-epithelial lymphocytes). Conclusions - The method revealed 100\% sensitivity and $99.3 \%$ specificity. Because it is not an invasive method it can be used for the screening of atypical and latent forms of celiac disease to avoid serial biopsies and to control adherence to a gluten-free diet with implications in the prevention of malignancy in celiac disease.

HEADINGS - Celiac disease, diagnosis. Autoantibodies, analysis. Fluorescent antibody technique.

\footnotetext{
* Service of Gastroenterology and Digestive Endoscopy, "Hospital Cajuru”. Service of Gastroenterology, Federal University of Paraná, Curitiba, PR, Brazil.

** Laboratory of Immunopathology, "Hospital de Clínicas", Federal University of Paraná.

*** Service of Gastroenterology, Federal University of Paraná.

Address for correspondence: Dr. Lorete Maria da Silva Kotze - Rua Bruno Filgueira, 369 - Cj. 1205 - 80240-220 - Curitiba, PR, Brazil. e-mail: loretekotze@hotmail.com
} 


\section{INTRODUCTION}

Sensitivity to gluten can be defined as a state of high cellular and humoral immunological response to dietary gluten from wheat, barley, rye and oats. The spectrum consists of celiac disease, dermatitis herpetiformis, recurrent aphthae, nephropathy and arthropathy. Celiac disease $(C D)$ is the most frequent presentation and can occur at any age. According to MARSH ${ }^{(48)}$, the intestinal mucosa in CD can be "normal" or present changes ranging from mild alterations in mucosal architecture to mucosal atrophy. The number of intraepithelial lymphocytes (IEL) is increased. The gold standard for the diagnosis of this affection continues to be a small bowel biopsy. However, antibody tests are a useful adjunct in deciding whom to biopsy, for screening high risk groups and to control the adherence to a gluten-free $\operatorname{diet}^{(53)}$. Tests looking for circulating antibodies to gliadin (AGA), reticulin (ARA), endomysium (EmA IgA) and more recently for tissue transglutaminase (tTG) have been reported ${ }^{(22,59)}$. The use of these tests can result in a dramatic increase in the prevalence of CD because asymptomatic forms can be detected ${ }^{(65)}$. The sensitivities and specificities of these tests varied from centre to centre but improved with the use of class specific immunoglobulins $(\operatorname{Ig} \mathrm{A})^{(26)}$.

Antibodies directed against smooth muscle fibers in the muscularis mucosae from primates (antiendomysial antibody - EmA IgA) have been described by CHORZELSKI et al. ${ }^{(15)}$ and are closely related to the reticulin antibody (ARA) described by SEAH et al. ${ }^{(60)}$ in 1971. In 1995, VOLTA et al. ${ }^{(71)}$, using human umbilical cord instead of monkey's esophagus as substrate, showed the same specificity and sensitivity of EmA IgA in both techniques. These data were then confirmed by BAGNASCO et al. ${ }^{(6)}$ in relatives of patients with CD.

After a gluten-free diet, the immunological reactions in the mucosa gradually vanished, antiendomysium antibodies decreased in peripheral blood, disappearing approximately 3 months later. If gluten is ingested, the same immunological phenomenon occurs and the antibodies rise again more quickly than AGA or $\mathrm{ARA}^{(43)}$, and even mucosal lesions can be retarded, although the number of intra-epithelial lymphocytes immediatly rises. Nowadays, EmA IgA and tTG are considered to be the best markers showing high sensitivity and specificity and complete overlap ${ }^{(61)}$, since endomysial autoantigen was recently identified as $\mathrm{tTG}^{(22)}$.

In first-degree relatives of celiac patients antibodies can be detected even when symptoms are absent $(5-13 \%)^{(67)}$. The small bowel mucosa can be preserved or exhibit alterations suggesting $\mathrm{CD}^{(68)}$. The same findings can be observed in the normal population, and therefore blood tests should be used for screening for the affection. In conclusion, there are atypical or monosymptomatic presentations of CD and, according to FERGUSON et al. ${ }^{(25)}$, active, silent, latent and potential forms.

In $\mathrm{CD}$, about $10 \%$ to $12 \%$ of the patients can exhibit $\operatorname{IgA}$ deficiency ${ }^{(16)}$. This is the reason why total serologic levels of this immunoglobulin are determined to avoid false-negative results in EmA $\operatorname{Ig} \mathrm{A}^{(8,20)}$.

The aims of the present study were to determine the specificity and sensitivity of EmA IgA antibodies by applying immunofluorescence techniques to Brazilian celiac patients at diagnosis, after a varying period of treatment to confirm the adherence to a gluten-free diet, and as screening in first-degree relatives. Another objective was to compare the findings with those observed in other gastrointestinal diseases and with the normal population from the same geographic area (Southern Brazil).

\section{PATIENTS, MATERIAL AND METHODS}

\section{Selection of individuals}

A total of 392 individuals from southern Brazil were studied and divided into four groups (Table 1)

TABLE 1 - Healthy population and patients studied

\begin{tabular}{lccc}
\hline Diagnosis & Number & Sex & Age mean(years) \\
\hline Group I - Controls & 126 & 86 F $40 \mathrm{M}$ & $25.2(1-71)$ \\
Group II - Celiac disease & & & $40.6(3-69)$ \\
II-A At diagnosis & 18 & 13 F 5 M & $29.1(2-77)$ \\
II-B Adherent to a gluten-free diet & 24 & 18 F 6 M & $26.5(9-56)$ \\
II-C Non-adherent to a gluten-free diet & 15 & 11 F $4 \mathrm{M}$ & $31.7(2-75)$ \\
Group III - First-degree relatives & 115 & 61 F 54 M & $39.7(1-71)$ \\
Group IV - Other gastrointestinal diseases & 94 & $63 \mathrm{M} 31 \mathrm{M}$ & \\
TOTAL & 392 & & \\
\hline
\end{tabular}

\footnotetext{
* $\mathrm{M}=$ Males
}

$\mathrm{F}=$ Females 
Group I - Control Group: 126 healthy individuals from the population of the same geographic area, 86 females and 40 males, mean age 25.2 years ( $01-71$ years);

Group II-Celiac Group: 57 patients were subdivided into II-A: 18 patients at diagnosis, 13 females and 5 males, mean age 40.6 years (3-69 years);

$I I-B: 24$ patients who adhered to a gluten-free diet, 18 females and 6 males, mean age 29.1 years (2-77 years);

II-C: 15 patients non-adherent to a gluten-free diet (sporadic, eventual or frequent ingestion of gluten), 11 females and 4 males, mean age 26.5 years (9-56 years).

Group III - First-Degree Relatives: 115 individuals from 39 celiac families, following a normal diet, 61 females and 54 males, mean age 31.7 years (2-75 years).

Group IV - Other Gastrointestinal Diseases: 94 patients, 63 females and 31 males, mean age 39.7 years (01-71 years) whose final diagnoses were: Crohn's disease 19, ulcerative colitis 24, irritable bowel syndrome 35 , and with different disorders 16 (lactose intolerance seven, diarrhea post-gastroenteritis three, immunoproliferative disease of the small intestine three, chronic pancreatitis one, refractory anemia one, and diverticular disease of the colon one)

\section{Diagnosis of celiac disease}

The diagnosis of celiac disease was based on the criteria established by the European Society of Pediatric Gastroenterology and Nutrition $(\text { ESPGAN) })^{(51)}$ and revised by WALKER-SMITH et al. ${ }^{(72)}$. The intestinal biopsies were performed with the Crosby-Kugler capsules (College Park Instruments, MD, USA) or with an endoscope (Olympus, Japan) ${ }^{(27,}$ ${ }^{31,40)}$. Histopathological examination was performed by a pathologist who was unaware of the clinical and laboratory findings. The IEL were counted according to FERGUSON and MURRAY ${ }^{(25)}$. For the healthy Brazilian population from the same geographic area the normal number of IELs per 100 epithelial cells was $24(24 \%)^{(41)}$. To control the diet, an interview was held by the same physician with questions concerning transgression of the dietary recommendations. Patients with the ingestion of more than $10 \mathrm{mg}$ of gliadin per day were considered 'nonstrict' or 'non-adherent'.

\section{Diagnosis of other gastrointestinal diseases}

The diagnosis of the other gastrointestinal diseases was made after completing a protocol prepared for the study of intestinal pathologies. The diagnosis of inflammatory bowel disease (IBD) Crohn's disease and ulcerative colitis - was made on the basis of radiologic, endoscopic and histological data. The other affections were diagnosed after special examinations based on clinical data.

\section{Serologic studies}

Serum samples were taken from all the individuals after they gave informed consent to participate in the study and aliquots were frozen for later examination.

Total serum level of immunoglobulin A was determined in all groups by turbidimetry ${ }^{(63)}$ in order to avoid a false-negative result due to $\operatorname{IgA}$ deficiency. IgA deficiency was defined as serum $\operatorname{IgA}$ less $5 \mathrm{mg} \%$.

Tests for EmA IgA were performed by an indirect immunofluorescence assay as previously described ${ }^{(44)}$, using human umbilical cord as substrate. Briefly, the cryostatic tissue sections were mounted and fixed on microscope slides. Serum samples diluted 1/2.5, 1/5 and 1/10 with phosphate-buffered saline were applied to the slides which were incubated for 30 minutes at room temperature. This initial dilution was chosen because no residual staining was seen at this or higher titres. After washing three times with phosphate-buffered saline for 5 minutes, the sections were covered with 1:80 fluorescein-conjugated goat anti-human IgA (Kallestad) for 30 minutes, washed again with phosphate-buffered saline, mounted in alkaline glycerin buffer and examined by fluorescence microscopy (Carl Zeiss) by two different observers. Sera were considered positive if fluorescence was seen at a dilution of 1:2.5 or greater. All positive sera were titrated up to the end point. The highest dilution yielding a positive reaction was reported as the result. Positive and negative controls were used for each batch.

\section{Statistics}

Data were analyzed statistically by the chi-square test with $1 \%$ and $5 \%$ confidence intervals.

\section{RESULTS}

Total IgA levels were below normal values in four individuals (two first-degree relatives and two with other gastrointestinal disease). These individuals were EmA IgA negative, and when IgG was used as conjugate EmA continued to be negative. The results of EmA IgA are summarized in Table 2.

One patient from the normal population (Group I) was EmA IgA positive $1 / 10$, but refused to undergo an intestinal biopsy.

EmA IgA was detected in all the celiac patients at diagnosis (Group II-A) and while on a gluten-containing diet (Group II-C). The antibody titer was widely distributed, ranging from 1:2.5 to 1:80 (Fig. 1). EmA IgA was negative in all the patients adhering to a gluten-free diet (Group II-B). These findings revealed 100\% sensitivity of this test. 
Kotze LM da S, Utiyama SR da R, Nisihara RM, Zeni MPB, Sena MG de, Amarante HMS. Antiendomysium antibodies in Brazilian patients with celiac disease and their first-degree relatives

TABLE 2 - Positivity of EmA IgA in the groups studied

\begin{tabular}{lcc}
\hline GROUPS & EmA IgA POSITIVE & EmA IgA NEGATIVE \\
\hline Group I - Control & $1(0.8 \%)$ & $125(99.2 \%)$ \\
Group II - Celiac disease & & 00 \\
II-A At diagnosis & $18(100 \%)$ & $24(100 \%)$ \\
II-B Adherent to a gluten-free diet & 00 & 00 \\
II-C Non-adherent to a gluten free diet & $15(100 \%)$ & $97(84.4 \%)$ \\
Group III - First-degree relatives & $18(15.6 \%)$ & $93(98.9 \%)$ \\
Group IV - Other gastrointestinal disease & $1(1.1 \%)$ & $339(86.5 \%)$ \\
Total & $53(13.5 \%)$ & \\
\hline
\end{tabular}

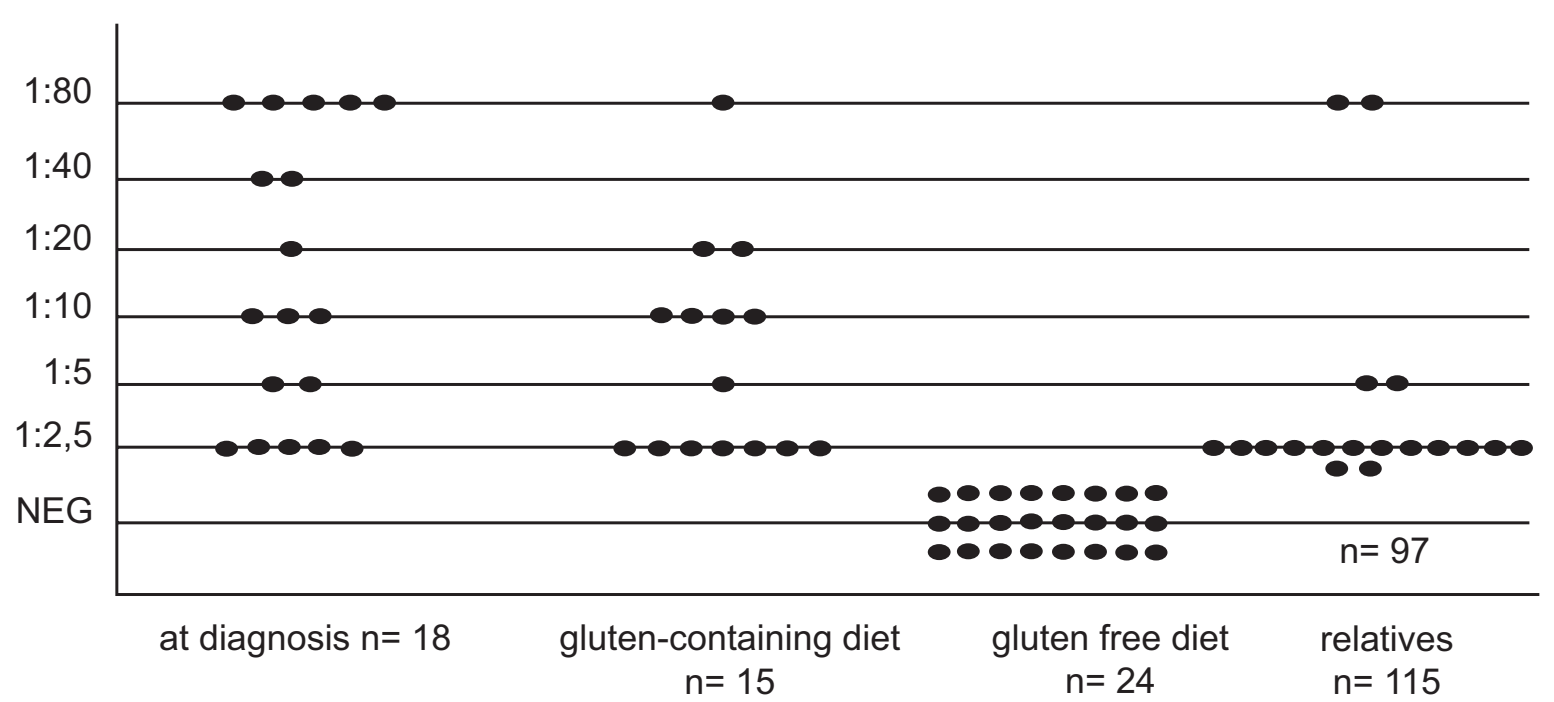

FIGURE 1 - EmA IgA titers in celiac patients and their relatives

Of the 115 first-degree relatives of celiac patients (Group III) $18(15.65 \%)$ were positive, showing statistical significance in relation to the control population $(P<0.0001)$ (Fig. 2). EmA IgA titers ranged from $1: 2.5$ to $1: 80$ in this group (Fig. 1). Among the positive relatives there were seven mothers $(38.88 \%)$, four fathers (22.22\%), four children $(22.22 \%)$ and three siblings $(16.66 \%)$. The female sex predominated. Only seven relatives agreed to an intestinal biopsy (Table 3): one (EmA IgA 1/80) presented total villous atrophy; one (EmA $\operatorname{IgA} 1 / 5)$ and five (EmA $\operatorname{IgA} 1 / 2.5)$ showed preserved intestinal architeture but presented an increased number of intra-epithelial lymphocytes (mean number, 36\%). The normal number reported for a healthy Brazilian population from the same geographic area was 24 IELs per 100 epithelial cells or $24 \%{ }^{(41)}$.

Including the celiac group and its relatives, there were three families with two celiac patients (two with twins) and two families with three persons affected.

In all the patients with Crohn's disease, irritable bowel syndrome and other gastrointestinal diseases, EmA IgA was negative (Group IV). One patient with ulcerative colitis (positive for EmA IgA 1/80) had epilepsy and Down's syndrome and an intestinal biopsy revealed celiac disease with total villous atrophy.

Considering one positive individual in Group I and one in Group IV, the specificity of EmA IgA can be estimated at $99.3 \%$. 


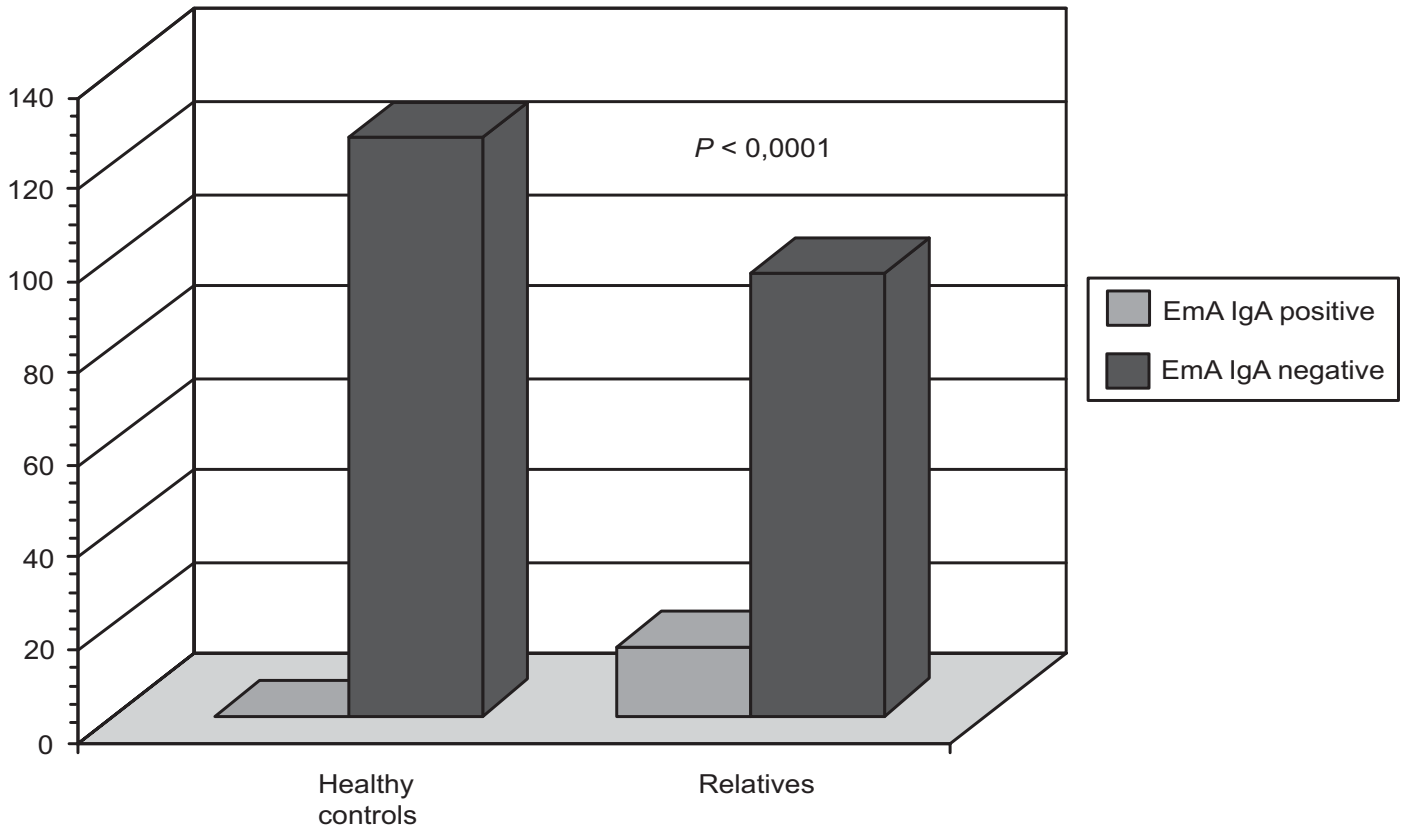

FIGURE 2 - EmA IgA in relatives and healthy population from southern Brazil

TABLE 3 - Data relating to first-degree relatives of the celiac patients with duodenal biopsy

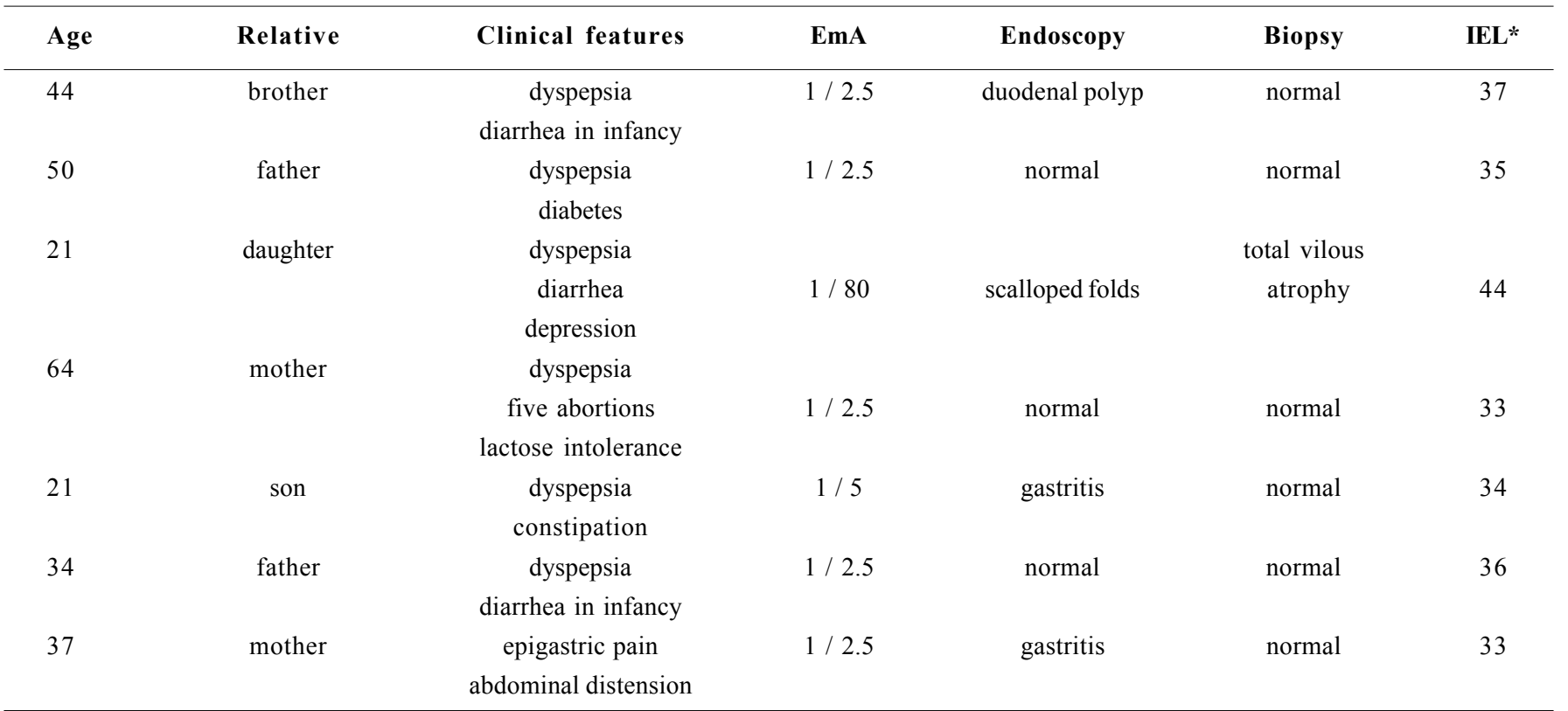

IEL $=$ number of intra-epithelial lymphocytes 


\section{DISCUSSION}

The South region of Brazil was settled mainly by Europeans and presents a high degree of ethnic admixture. Thus the diseases described in this geographic area are very similar to those described in developed countries even considering variations determined by environmental factors. KOTZE and FERREIRA ${ }^{(39)}$, in 1977 reported $76 \%$ of celiac patients with HLA B8 and $6 \%$ in the healthy population, but the real prevalence of $\mathrm{CD}$ in this part of the country must be higher than the data previously reported ${ }^{(7,42)}$. In the present study, only one person in the control group presented EmA IgA positive $1 / 10$, but without a biopsy there were no sufficient criteria to establish the diagnosis of CD or to indicate a lifelong gluten-free diet. We believe that a diagnostic trial of gluten restriction in lieu of a biopsy can never be justified ${ }^{(27)}$.

\section{Patients}

In the present study there was a prevalence of female patients, in agreement with data reported for different countries ${ }^{(56)}$. The mean age of the celiac patients at diagnosis (40.6-Group II-A) was higher than the mean age of the other groups (29.1 for Group II-B and 26.5 for Group II-C), but the difference was nonsignificant. We call attention to the fact that the diagnosis of $\mathrm{CD}$ was performed in 66 year old persons, thus showing that CD can be found at any age. HANKEY and HOLMES ${ }^{(34)}$ showed that $19 \%$ of the adult celiac patients studied were diagnosed after the age of 60 . Although the majority presented new gastrointestinal complaints, many had been seen in several clinics for these symptoms and received a variety of diagnoses, including irritable bowel syndrome and colitis. These data are similar to our findings.

The reason for studying children above 2 years of age was that EmA IgA can appear after the second year of life. It has been suggested that the sensitivity of EmA IgA may be age-dependent ${ }^{(11)}$. In this experience only two children were above 2 years of age: one from the control group and one with chronic diarrhea after gastroenteritis. For children aged less than 2 years AGA IgA can be a better marker ${ }^{(4,58)}$.

\section{IgA deficiency}

IgA deficiency is defined as serum IgA less than $5 \mathrm{mg} \%$. $\operatorname{Ig} \mathrm{A}$ deficiency is approximately 10 times more common in people with $\mathrm{CD}$ than in the general population. Several investigators recommend routine checking for IgA deficiency in laboratories that perform CD serology $\mathrm{y}^{(13,}$

${ }^{20)}$ because EmA IgA will be falsely negative in $\operatorname{IgA}$-deficient individuals ${ }^{(30,57)}$. Current serologic assays used for the diagnosis of CD are highly sensitive and highly specific, especially when using IgArather than IgG-based antibody tests, but IgA-deficient CD patients can exhibit IgG-class $\mathrm{EmA}^{(8)}$. In this study, four individuals were considered IgA deficient and remained negative with IgG class EmA.

LOCK and UNSWORTH ${ }^{(45)}$ reported that checking all routine samples for IgA deficiency seems excessive and more likely to identify non-CD cases with low IgA and suggested that patients with hightitre IgG AGA but no EmA IgA positivity can be checked for IgA deficiency.

\section{Considerations about EmA}

Human umbilical cord is an excellent substitute for monkey's esophagus to determine endomysial antibodies in CD diagnosis ${ }^{(6,37)}$. Monkey's esophagus is ethically questionable for large scale screening ${ }^{(71)}$. The endomysial antibody has been found to have a greater specificity and sensitivity ${ }^{(15,33)}$. Some authors stated that it has never been found in healthy controls or in other gastrointestinal diseases, including ulcerative colitis and Crohn's disease ${ }^{(33,36)}$. In the present study, a patient with ulcerative colitis was EmA IgA positive 1/80 but presented Down's syndrome and epilepsy. After intestinal biopsy total villous atrophy was shown and the diagnosis of CD could be confirmed. These associations have also been described by other authors ${ }^{(17,28)}$.

The effect of a gluten-free diet can be monitored by means of serological tests and a positive test result often indicates gluten ingestion $^{(46)}$. In Group II-B consisting of celiac patients adhering to a gluten-free diet, EmA IgA was negative in all, thus supporting the use of this test to control the diet. TRONCONE et al. ${ }^{(64)}$ called attention to slight dietary transgressions and a negative test, mainly in adolescents. Our results show that EmA was $100 \%$ positive for untreated patients and for celiacs non-adhering to the diet and disagree with those reported by McMILLAN et al. ${ }^{(50)}$ who found that $89 \%$ of their patients with untreated celiac disease had a positive EmA measured by immunofluorescence. However, FERREIRA et al. ${ }^{(26)}$ showed $100 \%$ positivity to EmA for untreated celiac disease in a predominantly adult population similar to that studied here. The data of our study are in agreement with several authors from different countries, as can be seen in Table $4^{(3,10,12,14,19,23,26,32,33,49,55,66,70)}$.

The most effective test for the diagnosis of active $\mathrm{CD}$ was the assessment of antiendomysium antibodies ${ }^{(12)}$. We may conclude that celiac patients with gluten in their diets presented active disease, although they reported few or no symptoms. Since these antibodies are highly sensitive and specific, we regard their use as a confirmatory test to assess the indication of an intestinal biopsy.

\section{Titer variaton}

Nearly all individuals with persistent gluten intolerance produce antibodies at some time, but they show a wide individual variation as 
Kotze LM da S, Utiyama SR da R, Nisihara RM, Zeni MPB, Sena MG de, Amarante HMS. Antiendomysium antibodies in Brazilian patients with celiac disease and their first-degree relatives

TABLE 4 - Sensitivity and specificity of EmA IgA antibodies in untreated celiac patients reported by different authors in various countries

\begin{tabular}{|c|c|c|c|c|}
\hline AUTHOR & YEAR & COUNTRY & SENSITIVITY\% & SPECIFICITY\% \\
\hline Hällström & 1989 & Finland & 91 & 100 \\
\hline Calabuig et al. & 1990 & Spain & 100 & 98 \\
\hline Ceccarelli et al. & 1990 & Italy & 100 & 100 \\
\hline Ferreira et al. & 1992 & England & 100 & 100 \\
\hline Mascart-Lemone et al. & 1992 & Belgium & 100 & 100 \\
\hline Grodzinski et al. & 1995 & Suisse & 98 & - \\
\hline Pacht et al. & 1995 & Israel & 100 & 100 \\
\hline Vogelsang et al. & 1995 & Austria & 100 & 100 \\
\hline Boige et al. & 1996 & France & 88 & 100 \\
\hline Valdimarsson et al. & 1996 & Sweden & 74 & 100 \\
\hline Del Rosario et al. & 1998 & USA & 100 & 100 \\
\hline Feighery et al. & 1999 & Ireland & 100 & - \\
\hline Arranz et al. & 1999 & Spain & 100 & - \\
\hline Kotze et al. & 2000 & Brazil & 100 & 99.3 \\
\hline
\end{tabular}

regards time, type and quantities of the antibodies they produce ${ }^{(11)}$. This fact can explain the different titers encountered by different authors and in this study (Fig. 1). There was no difference in the prevalence of these antibodies between men and women or according to patient age, validating the present data. The EmA IgA titers have been shown to correlate with the severity of the mucosal abnormalities $^{(26)}$.

\section{Time of gluten comsumption}

In this study, the patients had been under treatment for more than one year, with recommendation of gluten restriction. Time of gluten comsumption is an important factor, as demonstrated by CALABUIG et al. ${ }^{(12)}$, in Spain: when the time was less than 6 months the EmA IgA test was positive in $83 \%$ of cases and when the time was more than 6 month, it was positive in $100 \%$. Our data showed $100 \%$ negativity for EmA after 1 to 27 years of adherence to a gluten-free diet (Group II-B) and $100 \%$ positivity for nonadherence (Group II-C). The difference in titers (Fig. 1) can be attributed to the duration of gluten consumption, in line with the kinetic characteristics of the antibody following gluten challenge, as reported by KAPUSCINSKA et al. ${ }^{(36)}$. FEIGHERY et al. ${ }^{(23)}$ suggested that continued gluten exposure rather than tissue damage is the determining factor in the generation of EmA.

\section{Relatives}

Family members of CD patients are at increased risk for CD $(5 \%$ $13 \%$ ) depending on the screening procedure (Table 5$)^{(6,18,43,52,56,73)}$. In this study we found EmA IgA positivity in $15.65 \%$ (18 of 115 relatives from 39 families). There was a predominance of parents (11: 7 mothers and 4 fathers), followed by 4 children ( 2 sons and 1 daughter) and 3 siblings ( 2 females and 1 male). VITORIA et al. ${ }^{(69)}$ called greater attention to siblings of celiac patients. As three families presented

TABLE 5 - Comparison of EmA IgA antibody positivity in first-degree relatives of celiac patients reported by different authors in various countries

\begin{tabular}{lcccc}
\hline Author & Year & Country & Number & \% \\
\hline Reunala & 1996 & Finland & 999 & 13.7 \\
Yannakou et al. & 1997 & England & 104 & 7.6 \\
Bagnasco et al. & 1997 & Italy & 187 & 5.8 \\
De Rosa & 1999 & Argentina & 639 & 9.0 \\
Mustalahati et al. & 1999 & Finland & 466 & 9.7 \\
Kotze et al. & 2000 & Brazil & 115 & 15.6 \\
\hline
\end{tabular}


two affected persons (two twins) and two families with three members were positive, we could demonstrate a familial predisposition with genetic implications, reinforcing the findings of KORPONAY-SZABÓ et al. ${ }^{(38)}$ who found multiple cases in the same families.

As these antibodies offer great sensitivity and specificity, we regard them as a confirmatory test for assessing the indication of an intestinal biopsy. Only seven relatives agreed to undergo an intestinal biopsy (Table 3). Most relatives fear the procedure of small bowel biopsy and some may even be intimidated by medical examination. The refusal to undergo this procedure was also reported by other authors ${ }^{(6,73)}$. Of the patients studied by MARSH et al. ${ }^{(47)}$, one presented total villous atrophy and EmA IgA 1/80, and 6 with low titers had preserved the mucosal architecture, but with higher IEL number. ARRANZ and FERGUSON $^{(2)}$ demonstrated that a celiac-like intestinal antibody pattern and a high IEL count may be markers of latent gluten-sensitive enteropathy. Even so it was not possible to prove that the IEL were gamma/delta $\mathrm{T}$ cells considered to be an important marker for $\mathrm{CD}^{(1)}$. These findings also confirm data reported by FERREIRA et al. ${ }^{(26)}$ who showed a correlation between EmA IgA titers and mucosal alterations.

In Brazil, this is the first study aimed at detecting EmA IgA in CD in relation to the healthy population and for a differential diagnosis with other gastrointestinal diseases. Likewise, it is the first to report about EmA IgA in relatives of celiac patients (15.65\%). NUNES et al. ${ }^{(54)}$ reported $5.8 \%$ positivity for antigliadin antibodies (AGA IgA) in another region, but our percentage was greater, probably because of a more accurate test. In another region of Brazil, GANDOLFI et al. ${ }^{(29)}$ reported $1.0 \%$ of blood donors positive for EmA IgA.

Today, according to ASCHER et al. ${ }^{(4)}$, for screening unselected populations with a low prevalence of the disease, in which a test with maximum specificity is desired, antiendomysium antibodies have a sufficiently high predictive value to be of practical use. Future research will clarify the pathogenesis of this intriguing affection and perhaps simpler tests will be of help in the diagnosis and control of the diet, with implications in the prevention of the malignancy ${ }^{(35,62)}$.

\section{CONCLUSIONS}

In this study, EmA IgA showed $99.3 \%$ specificity and $100 \%$ sensitivity, indicating the usefulness of the test for detecting glutensensitive enteropathy as a differential diagnosis of gastrointestinal disease, in relatives of celiac patients and for monitoring dietary treatment in patients with $\mathrm{CD}$. The use of human umbilical cord as a substrate is ethical ${ }^{(5,71)}$. Serological tests can be of help to identify $\mathrm{CD}$ in primary care ${ }^{(21)}$ and, as they are not an invasive method, they can avoid multiple small bowel biopsies.

Kotze LM da S, Utiyama SR da R, Nisihara RM, Zeni MPB, Sena MG de, Amarante HMS. Anticorpos antiendomísio em pacientes brasileiros com doença celiaca e em seus familiares de primeiro grau. Arq Gastroenterol 2001;38(2):94-103.

RESUMO - Racional - Dados de literatura têm mostrado alta especificidade dos anticorpos antiendomísio da classe IgA (EmA IgA) na doença celíaca. O pequeno número de trabalhos brasileiros motivaram o presente estudo. Objetivos - Determinar a sensibilidade e especificidade dos anticorpos antiendomísio da classe IgA em celíacos brasileiros ao diagnóstico, após tratamento para confirmar a aderência à dieta isenta de glúten e como rastreatmento em familiares de primeiro grau. Métodos - Estudo clínico e sorológico abrangente foi realizado investigandose a presença destes anticorpos em 392 indivíduos da região sul do Brasil. Empregou-se imunofluorescência indireta, tendo como substrato cordão umbilical humano, e os níveis de IgA sérica foram determinados por turbidimetria, em todos os grupos. O estudo compreendeu 57 celíacos (18 ao diagnóstico, 24 aderentes à dieta e 15 com transgressões maiores ou menores), 115 familiares de celíacos (39 famílias), 94 pacientes com outras doenças gastrointestinais e 126 indivíduos sadios da população. Resultados - Os dados evidenciaram 100\% de positividade nos pacientes recém diagnosticados e nos consumidores de glúten, em contraste com $0 \%$ nos aderentes à dieta. Um individuo do grupo controle foi positivo, mas recusou biopsia. No grupo de outras doenças gastrointestinais, um paciente positivo, portador de retocolite ulcerativa, também apresentava síndrome de Down, epilepsia e a biopsia intestinal diagnosticou doença celíaca. Tais dados mostram 99.3\% de especificidade. Dezoito familiares foram positivos para anticorpos antiendomísio da classe IgA (15.65\%) e a correlação com a população sadia foi estatisticamente significativa. Em sete foi realizada biopsia que demonstrou atrofia total de vilosidades em um e seis com arquitetura preservada, porém com número elevado de linfócitos intra-epiteliais. Conclusões - O método revelou $100 \%$ de sensibilidade e $99.3 \%$ de especificidade. Por não ser invasivo, pode ser usado para rastreamento de formas atípicas ou latentes de doença celíaca, evita biopsias seriadas e serve para controle da aderência à dieta, com implicações na prevenção de malignidade na doença celíaca.

DESCRITORES - Doença celíaca, diagnóstico. Auto-anticorpos, análise. Imunofluorescência. 


\section{REFERENCES}

1. Arató A, Hacsek G, Savilahti E. Immunohistochemical findings in the jejuna mucosa of patients with celiac disease. Scand J Gastroenterol 1998;33 Suppl 228:3-10.

2. Arranz E, Ferguson A. Intestinal antibody pattern of celiac disease: Occurrence in patients with normal jejunal biopsy histology. Gastroenterology 1993;104:1263-72.

3. Arranz MC, Ayesta A, Riñon M, Maruri N, Vitoria JC, Garcia Masdeval MD, Arrieta A. Relationship between antigliadin, antiendomysial and tissue transglutaminase antibodies in coeliac disease [abstract]. Eight International Symposium on Coeliac Disease, Italy, 1999. Poster 033

4. Ascher H, Hahn-Zoric M, Hanson LA, Kilander AF, Nilsson LA, Tlaskalova H. Value of serologic markers for clinical diagnosis and population studies of coeliac disease. Scand J Gastroenterol 1996;31:61-7.

5. Atkinson K, Tokmakajian S, Watson W, Gregor J. Evaluation of the endomysia antibody for celiac disease: operating properties and associated cost implications in clinical practice. Can J Gastroenterol 1997;11:673-7.

6. Bagnasco M, Montagna P, De Alessandri A, Castellano E, Pesce GP, Gatti R. IgA antiendomysium antibodies in human umbilical cord sections as a screening test in relatives of patients with celiac disease. Allergy 1997;52:1017-21.

7. Barbieri D. Multicentric study about the prevalence of celiac disease in Brazil. Boletim da Sociedade Paulista de Gastroenterologia Pediátrica e Nutrição 1993;1(2). Beutner EH, Kumar V, Chorzelski TP, Szaflarska-Czerwionka M. IgG endomysial antibobies in IgA-deficient patient with coeliac disease. Lancet 1989;1:1261-2.

9. Beutner EH, Chorzelski TP, Kumar V, Leonard J, Krasny S. Sensitivity and specificity of IgA class antiendomysium antibodies for dermatitis herpetiformis and findings relevant to their pathogenic significance. J Am Acad Dermatol 1996; 15:464-73

10. Boige V, Bouhnik Y, Delchier JC, Jian R, Matuchansky C, Andre C. Antiendomysium and anti-reticulin antibodies in adults with celiac disease followedup in the Paris area. Gastroenterol Clin Biol 1996;20:931-7.

11. Burgin-Wolff A, Gaze H, Hadziselimovic F, Huber H, Lentze MJ, Nusslé D, Reymond-Berthet C. Antigliadin and antiendomysium antibody determination for coeliac disease. Arch Dis Child 1991;66:941-7.

12. Calabuig M, Torregosa R, Polo P, Tuset L, Tomás C, Alvarez V, Garcia-Vila A Brines J, Vilar P Farré C, Varea V. Serological markers and celiac disease: a new diagnostic approach? J Pediatr Gastroenterol Nutr 1990;10:435-42.

13. Cataldo F, Marino V, Ventura A, Bottaro G, Corazza GR. Prevalence and clinical features of selective immunoglobulin A deficiency in coeliac disease: an Italian multicentre study. Gut 1998;42:362-5.

14. Cecarelli M, Caiulo VA, Cortigiani L, Toscanelli A, Ughi C. Il ruolo degli anticorpi anti-endomisio nello screening e nel monitoraggio della malattia celiaca. Riv Ital Pediatr 1990;16:697.

15. Chorzelski TP, Sulej J, Tchorzewska H, Jablonska S, Beutner EH, Kumar V. IgA class endomysium antibodies in dermatitis herpetiformis and celiac disease. In Beutner EH, Nisengard, RJ, Albini, B, editors. Defined immunofluorescence and related cytochemical methods. New York. Ann NY Acad Sci 1983;420:325-34.

16. Collin P, Mäki M, Keyriläinen O, Hällström O, Reunala T, Pasternack A. Selective IgA deficiency and coeliac disease. Scand J Gastroenterol 1992;27:367-71.

17. Collin P, Mäki M. Associated disorders in coeliac disease. Clinical aspects. Scand J Gastroenterol 1994;29:769-75.

18. De Rosa S, Ruiz AG, Olmos M, Bottero A, de Davila MTG. Coeliac disease. Familiar screening [abstract]. Eight International Symposium on Coeliac Disease, Italy, 1999. Poster 058.

19. Del Rosario MA, Fitzgerald JF, Chong SK, Croffie JM, Gupta SK. Further studies of anti-endomysium and anti-gliadin antibodies in patients with suspected celiac disease. J Pediatr Gastroenterol Nutr 1998;27:191-5.

20. Dickey W, McMillan AS, McCrum EE, Evans AE. Association between serum levels of total IgA and IgA class endomysial and antigliadin antibodies: implications for coeliac disease screening. Eur J Gastroenterol Hepatol 1997;9:559-62.

21. Dickey W, McMillan AS, Hughes DF. Identification of coeliac disease in primaty care. Scand J Gastroenterol 1998;33:491-3.

22. Dieterich W, Ehnis T, Bauer M, Donner P, Volta U, Riecken EO, Schuppan D. Identification of tissue transglutaminase as the autoantigen of celiac disease. Nat Med 1997;3:797-801.

23. Feighery L, Feighery C, Whelan A, Patterson U, Collins C, Jackson J. The standard immunofluorescence EMA test is more sensitive and specific in the diagnosis of coeliac disease than a transglutaminase Elisa [abstract]. Eight International Symposium on Coeliac Disease, Italy, 1999. Poster 032.

24. Ferguson A, Murray D. Quantitation of intraepithelial lymphocytes in human jejunum. Gut 1971;12:988-94.
25. Ferguson A, Arranz E, O'Mahony S. Clinical and pathological spectrum of celiac disease - active, silent, latent, potential. Gut 1993;34:150-1.

26. Ferreira M, Lloyd Davies S, Butler M, Scott D, Clark M, Kumar P. Endomysial antibody: is it the best screening test for coeliac disease? Gut 1992;33:1633-7.

27. Frick TJ, Olsen WA. Celiac disease and the spectrum of gluten sensitivity. Gastroenterologist 1994;2:285-92.

28. Gale L, Wimalaratna H, Brotodiharjo A, Duggan JM. Down's syndrome is strongly associated with coeliac disease. Gut 1997;40:492-6.

29. Gandolfi L, Pratesi R, Cordoba JCM, Tauil PL, Catassi C. Prevalence of celiac disease among blood donors in Brazil. Am J Gastroenterol 2000;95:689-92.

30. Gillett HR, Freeman HJ. Serological testing in screening for adult celiac disease. Can J Gastroenterol 1999;13:265-9.

31. Gottrand F, Michaud L, Guimber D, Turck D. Comparison of fiberendoscopy and suction capsule for small intestinal biopsy in children with and without celiac disease. J Pediatr Gastroenterol Nutr 1999;28:353.

32. Grodzinski E, Jansson G, Skogh T, Stenhammar L, Fälth-Magnusson K. Antiendomysium and anti-gliadin antibodies as serological markers for coeliac disease in childhood: a clinical study to develop a practical routine. Acta Paediat $1995 ; 84: 294-8$.

33. Hällström O. Comparison of IgA-class reticulin and endomysium antibodies in coeliac disease and dermatitis herpetiformis. Gut 1989;30:1225-32.

34. Hankey GL, Holmes GK. Coeliac disease in the elderly. Gut 1994;35:65-7.

35. Holmes GK, Prior P, Lane MR, Pope D, Allan RN. Malignancy in coeliac diseaseeffect of a gluten free diet. Gut 1989;30:333-8.

36. Kapuscinska A, Zalewski T, Chorzelski TP, Sulej J, Beutner EH, Kumar V, Rossi T. Disease specificity and dynamics of changes in IgA class anti-endomysia antibodies in celiac disease. J Pediatr Gastroenterol Nutr 1987;6:529-34.

37. Kolho KL, Farkkila MA, Savilahti E. Undiagnosed coeliac disease is common in Finnish adults. Scand J Gastroenterol 1998;33:1280-3.

38. Korponay-Szabó I, Kovacs J, Lorincz M, Torok E, Goracz G. Families with multiple cases of gluten-sensitive enteropathy. Z Gastroenterol 1998;36:553-8.

39. Kotze LMS, Ferreira E. Coeliac disease and HLA system. Arq Gastroenterol 1977;14:231.

40. Kotze LMS, Pisani JC. Diagnosis of celiac disease with endoscopic biopsies [abstract]. 28 $8^{\text {th }}$ Brazilian Congress of Gastroenterology, São Paulo, 1982. A18

41. Kotze LMS. Histologic patterns and intra-epithelial lymphocytes of the small bowel mucosa in chronic diarrheas [thesis]. Curitiba: Federal University of Paraná; 1988.

42. Kotze, LMS, Utiyama SRR, Nisihara RM, Mocelin V, Carvalho RFA, Zeni MPB, Amarante HMS. Comparison of IgA class reticulin and endomysium antibodies for diagnosis and control of the diet in celiac disease. Arq Gastroenterol 1999;36:177-84.

43. Kumar V, Lerner A, Valeski JE, Beutner EH, Chorzelski TP, Rossi T. Endomysial antibodies in the diagnosis of celiac disease and the effect of gluten on antibody titers. Immunol Invest 1989;18:533-44.

44. Ladinser B, Rossipal E, Pittschieler K. Endomysium antibodies in coeliac disease: an improved method. Gut 1994;35:776-8.

45. Lock RJ, Unsworth DJ. Identifying immunoglobulin-A-deficient children and adults does not necessarily help the serologic diagnosis of coeliac disease. Pediatr Gastroenterol Nutr 1999;28:81-3.

46. Mäki M, Sulkanen S, Collin P. Antibodies in relation to gluten intake. Dig Dis, Sci $1998 ; 16: 330-2$.

47. Marsh MN, Bjarnason I, Shaw J, Ellis A, Baker R, Peters TJ. Studies of intestinal lymphoid tissue. XIV-HLA status, mucosal morphology, permeability and epithelial lymphocyte populations in the first-degree relatives of patients with coeliac disease. Gut 1990;31:32-6.

48. Marsh MN. Mucosal pathology in gluten sensitivity. In: Marsh MN, editor Coeliac disease. Oxford: Blackwel; 1992. p.136-91.

49. Mascart-Lemone F, Van den Broeck J, Cadranel S, Colombel JF. Serological aspects of coeliac disease. Acta Gastroenterol Belg, 1992;55:200-8.

50. McMillan SA, Watson RPG, McCrum EE, Evans AE. Factors associated with serum antibodies to reticulin, endomysium, and gliadin in an adult population. Gut 1996;39:43-7.

51. Meuwisse GW. Diagnostic criteria in coeliac disease. Acta Paediatr Scand 1970;59:461-3.

52. Mustalahti K, Sulkanen S, Holopainen P, Laurila K, Collin P, Partanen J, Mäk M. Undetected coeliac disease in Finnish multiple case families [abstract]. Eight International Symposium on Coeliac Disease, Italy, 1999. Poster D 45.

53. Nehra V. New clinical issues in celiac disease. Gastroenterol Clin North Am 1998;27:453-65

54. Nunes CR, Medeiros EH, Leser P, Patricio FR, Wheba J. Dosage of the antibody antigliadin in first-degree relatives of celiac patients. Arq Gastroenterol 1998;35:69-73. 
55. Patcht A, Sinai N, Hornstein L, Kumar V, Ish-Shalom N, Lerner A. The diagnostic reliability of anti-endomysial antibody in celiac disease: the north Israel experience. Israel J Med Sci 1995;31:218-20.

56. Reunala $\mathrm{T}$. Incidence of familial dermatitis herpetiformis. Br J Dermato 1996;134:394-8

57. Rittmeyer C, Rhoads JM. IgA deficiency causes false-negative endomysial antibody results in celiac disease. J Pediatr Gastroenterol Nutr 1996;23:504-6.

58. Romaldini CC, Barbieri D. Serum antigliadin immunoglobulin-A class antibodies in celiac disease. Arq Gastroenterol 1997;34:254-61.

59. Schuppan D, Dieterich W, Ehnis T, Bauer M, Donner P, Volta U, Riecken EO. Identification of the autoantigen of celiac disease. Ann N Y Acad Sci 1998;859:121-6.

60. Seah PP, Fry L, Hoffbrand AV, Holborow EJ. Tissue antibodies in dermatitis herpetiformis and adult coeliac disease. Lancet 1971;1:834-6.

61. Sulkanen S, Collin P, Laurila K, Mäki M. IgA-and IgG-class antihuman umbilical cord antibody tests in adult coeliac disease. Scand J Gastroenterol 1998;33:251-4.

62. Swinson CM, Slavin G, Coles EC, Booth CC. Coeliac disease and malignancy. Lancet 1983;1:111-5.

63. Thomas L. Labor und Diagnose. Die medizinishe Verlagsgellschaft, Marburg; 1988.

64. Troncone R, Mayer M, Spagnuolo F, Maiuri L, Greco L. Endomysial antibodies as unreliable markers for slight dietary transgressions in adolescents with celiac disease. J Pediatr Gastroenterol Nutr 1995;21:69-72.

65. Tuthill DP, Hawkes N, Fifield R, Williams P, Jenkins HR. The rise of childhood coeliac disease following antibody testing introduction [abstract]. Eight International Symposium on Coeliac Disease, Italy, 1999. Poster 062.
66. Valdimarsson T, Franzen L, Grodzinsky E, Skogh T, Ström M. Is small bowel biopsy necessary in adults with suspected celiac disease and IgA antiendomysium antibodies? Dig Dis Sci 1996;41:83-7.

67. Vazquez H, Sugai E, Pedreira S, Katz S, Litwin N, De Rosa S, Ruiz J, Soifer G, Kogan Z, Boerr L, et al. Screening for asymptomatic celiac sprue in families. J Clin Gastroenterol 1995;21:130-3.

68. Vazquez H, Cabanne A, Sugai E, Fiorini A, Pedreira S, Maurino E, Smecuol E, Dezi R, Niveloni S, Valero J, De Rosa S, Litwin N, Kogan Z, Boerr LA, Bai JC Serological markers identify histologically latent coeliac disease among firstdegree relatives. Eur J Gastroenterol Hepatol 1996;8:15-21.

69. Vitoria JC, Arrieta A, Astigarraga I, Garcia-Masdevall, Rodriguez-Soriano J. Use of serological markers as a screening test in family members of patients with celiac disease. J Pediatr Gastroenterol Nutr 1994;19:304-9.

70. Vogelsang H, Genser D, Wyatt J, Lochs H, Terenci P, Granditsch G, Penner E. Screening for celiac disease: a prospective study on the value of noninvasive tests. Am J Gastroenterol 1995;90:394-8.

71. Volta U, Molinaro M, de Franceschi L, Fratangelo D, Bianchi FB. IgA antiendomysial antibodies on human umbilical cord tissue for celiac disease screening. Save both money and monkeys. Dig Dis Sci 1995;40:1902-5.

72. Walker-Smith JA, Guandalini S, Schimitz J, Schmerling DH, Visacorpi JK. Revised criteria for diagnosis of coeliac disease. Arch Dis Child 1990;65:909-11.

73. Yiannakou JY, Ellis HJ, Biagi FL. Two stage antibody screening for the diagnosis of coeliac disease in relative of patients. Gut 1997;41(Suppl 3):A72.

Recebido em 22/8/2000 Aprovado em 14/2/2001. 